\title{
Analisis genetik lokus CSF1PO, TH01, dan TPOX short tandem repeats pada etnis minangkabau
}

\author{
Taufik Hidayat, Rika Susanti \\ Bagian IImu Kedokteran Forensik, Fakultas Kedokteran, Universitas Andalas \\ Korespondensi: Taufik Hidayat, email: taufikspf2017@gmail.com
}

\begin{abstract}
Abstrak
Identifikasi forensik terus mengalami kemajuan yang pesat sesuai dengan perkembangan ilmu pengetahuan dan teknologi kedokteran. Tujuan: Untuk mengetahui frekuensi alel-alel dan membuat data dasar alel-alel lokus CSF1PO, THO1 dan TPOX Short Tandem Repeats pada etnis Minangkabau. Metode: Penelitian ini merupakan penelitian deskriptif dengan sampel 30 orang coba beretnis Minangkabau, sesuai dengan kriteria inklusi dan eksklusi. Dilakukan isolasi DNA lokus CSF1PO, TH01 dan TPOX dan dilakukan sekuensing dengan kit experion DNA $1 \mathrm{~K}$. Alel yang didapat dianalisis dengan software EasyDNA. Hasil: Didapatkan frekuensi alel lokus CSF1PO yaitu 16 alel, lokus TH01 sebanyak 12 alel, dan lokus TPOX yaitu 10 alel. Frekuensi alel tertinggi CSF1PO yaitu 165 bp $(0,0167)$ dan alel 170 bp $(0,0167)$. Frekuensi alel tertinggi lokus TH01 yaitu 93 bp $(0,217)$. Frekuensi alel TPOX tertinggi adalah 85 bp $(0,267)$ Nilai heterozigositas observasi tertinggi terdapat pada lokus TPOX $(0,4)$ diikuti oleh lokus TH01 $(0,33)$ dan lokus CSF1PO $(0,2)$. Nilai power of discrimination tertinggi terdapat pada lokus CSF1PO $(0,98)$, TH01 $(0,973)$ dan TPOX $(0,949)$. Simpulan: didapatkan data frekuensi alel lokus CSF1PO, TH01, dan TPOX etnis Minangkabau. Lokus CSF1PO, TH01 dan TPOX dapat digunakan sebagai pembanding dalam identifikasi forensik.
\end{abstract}

Kata kunci: identifikasi; frekuensi alel; heterozigositas; power of discrimination

\begin{abstract}
Forensic identification continues to progress rapidly in accordance with the development of medical science and technology. Objectives: This study aims were to determine the alleles frequency and to establish alleles database of locus CSF1PO, THO1 and TPOX Short Tandem Repeats on Minangkabau ethnic. Methods: This research was a descriptive research with sample of 30 Minangkabau ethnic group, who meet the inclusion and exclusion criteria. DNA isolation was performed on CSF1PO, THO1 and TPOX loci and sequencing with experion DNA kit $1 \mathrm{~K}$. Results: The alleles obtained were analyzed with EasyDNA software. The allele frequency of CSF1PO locus were 16 alleles, locus TH01 were 12 alleles, and TPOX locus were 10 alleles. The highest allele frequency of CSF1PO were $165 \mathrm{bp}$ (0.0167) and $170 \mathrm{bp}$ (0.0167). The highest allele frequency of TH01 was $93 \mathrm{bp}(0.217)$. The highest allele frequency of TPOX was $85 \mathrm{bp}$ (0.267) The highest of observed heterozygosity was in TPOX (0.4) followed by THO1 (0.33) and CSF1PO (0.2). The highest power of discrimination values are in the CSF1PO locus (0.98), THO1 (0.973) and TPOX (0.949). Conclusions: was obtained frequency data allele locus CSF1PO, THO1 and TPOX ethnic Minangkabau. The focus of CSF1PO, THO1 and TPOX can be used as a comparison in forensic identification
\end{abstract}

Keywords: identification; allele frequency; observed heterozigosity; power of discrimination 


\section{PENDAHULUAN}

Selain untuk identifikasi korban bencana alam dan kecelakaan massal, proses identifikasi juga diperlukan untuk memecahkan kasus sipil, kriminal dan terorisme. Pertambahan populasi umat manusia membuat keperluan identifikasi menjadi sangat penting, terutama dalam memecahkan kasus-kasus sengketa keayahan, sengketa kekerabatan, keimigrasian, dan lain sebagainya. Pada ranah kriminal seperti kejahatan seksual, bayi yang tertukar di rumah sakit, perdagangan anak, perampokan dan terorisme, proses identifikasi korban dan atau pelaku sangat diperlukan. ${ }^{1,2}$

Seiring dengan perkembangan ilmu pengetahuan dan teknologi kedokteran, ilmu kedokteran forensik telah mengembangkan metode identifikasi yang berdasarkan metode ilmiah kedokteran seperti tanda-tanda khas dari golongan darah, sidik jari, odontologi, antropologi dan DNA. Kemajuan dibidang genetika molekuler melalui teknologi DNA typing sangat membantu proses identifikasi terutama jika sampel dalam jumlah yang sedikit, terkontaminasi dan terdegradasi. Analisis STR (Short Tandem Repeats) merupakan jenis pemeriksaan DNA saat ini dengan tingkat sensitivitas dan spesifisitas yang tinggi. ${ }^{2,3}$

STR merupakan pengulangan tetranukleotida 2-7 bp pada daerah 200$1000 \mathrm{bp}$ sehingga sangat unggul dalam membedakan individu. Untuk aplikasi forensik diperlukan data populasi dari suatu profil DNA tertentu. Apabila dari sampel barang bukti biologis diteliti profil DNA-nya, dan ternyata cocok dengan korban atau pelaku maka dapat dilakukan uji eksklusi profil DNA barang bukti biologis dari seluruh individu dalam populasi secara statistik. Uji tersebut menggunakan lokuslokus STR. Untuk itu diperlukan data tentang frekuensi alel lokus STR dalam suatu populasi atau etnik penduduk tertentu terutama di Indonesia. ${ }^{4-6}$

Penelitian ini bertujuan untuk mengetahui frekuensi alel-alel dan membuat data dasar alel-alel lokus CSF1PO, THO1 dan TPOX Short Tandem Repeats pada etnis Minangkabau.

\section{METODE}

Rancangan penelitian menggunakan desain deskriptif. Penelitian dilakukan di laboratorium Biomedik dan Bagian IImu Kedokteran Forensik Fakultas Kedokteran Universitas Andalas periode Agustus sampai November 2017. Subyek penelitian ini adalah 30 sampel DNA naracoba. Kriteria inklusi pada penelitian ini adalah sukarelawan laki-laki dan perempuan, etnis Minangkabau, sehat, berusia di atas 18 tahun serta menandatangani informed consent (bersedia diperiksa). Kriteria eksklusi adalah orang coba yang memiliki hubungan darah dan membatalkan keikutsertaan mengikuti penelitian oleh karena berbagai sebab. Kelayakan etik penelitian didapat dari komite etik penelitian Fakultas Kedokteran Universitas Andalas Padang. 
DNA genomik diisolasi dari sampel berupa darah menggunakan PureLink ${ }^{\circledR}$ Genomics DNA Kits, Invitrogen. Isolasi DNA dilakukan sesuai dengan prosedur kit yang secara garis besar terdiri atas tahap lisis sel, tahap pengikatan DNA, tahap pencucian, dan tahap elusi DNA. Untuk menganalisis hasil isolasi DNA, sebanyak $5 \mu$ l DNA genomik hasil isolasi dicampurkan dengan $1 \mu$ l loading dye (6x), kemudian dielektroforesis menggunakan gel agarose $1,5 \%$ yang telah diberi pewarna DNA berupa GelRed, dengan voltase $100 \mathrm{~V}$ selama 30 menit. Gel agarose kemudian diamati di bawah sinar UV menggunakan GelDoc. PCR masingmasing STR CSF1PO, THO1, dan TPOX dilakukan menggunakan primer CSFP01, TH01 dan TPOX menurut penelitian Baloglu dan Yigit (2011), F-CSF1PO 5'AGATATTAACAGTAACTGCCTTCA-3', rCSF1PO 5'-CAGATACTATCTCCTGGTGCA-3' . F-THO1 5'-CATTGGCCTGTTCCTCCCTTA-3,rTHO1 5'-GCAGGTCACAGGGAACACAGA-3. F-TPOX 5'-AGAACAGGCACTTAGGGAA-3', rTPOX 5'-AGCGTTTATTTGCCCAA-3'. ${ }^{7}$ Komposisi PCR untuk amplifikasi STR CSF1PO, THO1, dan TPOX pada sampel adalah sama yaitu, dilakukan menggunakan reagen Go Taq Green Master Mix dari Promega. Volume total reaksi adalah $15 \mu \mathrm{l}$, yang terdiri dari $7,5 \mu \mathrm{l}$ Go Taq Green Master Mix; $2 \mu \mathrm{l}$ DNA genomic (sampel); 0,5 $\mu$ l primer Forward CSF1PO, THO1, dan TPOX (10 $\mu \mathrm{M}) ; 0,5 \mu \mathrm{l}$ primer Reverse CSF1PO, THO1, dan TPOX $(10 \mu \mathrm{M}) ;$ dan $4,5 \mu \mathrm{lddH} 2 \mathrm{O}$.

Amplifikasi STR CSF1PO, THO1, dan TPOX dilakukan dengan kondisi PCR yang sama, yaitu: denaturasi awal pada suhu $95^{\circ} \mathrm{C}$ selama 3 menit, kemudian diikuti oleh siklus 35 siklus berulang, denaturasi lanjut pada $95^{\circ} \mathrm{C}$ selama 30 detik, annealing (penempelan primer) pada suhu $59^{\circ} \mathrm{C}$ selama 20 detik, dan elongasi pada suhu $72^{\circ} \mathrm{C}$ selama 30 detik, proses PCR diakhiri dengan tahap elongasi akhir pada suhu $72^{\circ} \mathrm{C}$ selama 5 menit. (kecuali untuk STR TPOX, suhu annealing adalah $53^{\circ} \mathrm{C}$ ).

Produk hasil ampifikasi PCR STR lokus CSF1PO, THO1, dan TPOX diamati dengan elektroforesis menggunakan gel agarose $1,5 \%$ yang telah diberi pewarna DNA GelRed. Sebanyak $5 \mu \mathrm{l}$ produk PCR dielektroforesis dengan voltase $100 \mathrm{~V}$ selama 60 menit, kemudian gel agarose diamati di bawah sinar UV menggunakan GelDoc. Selanjutnya dilakukan sekuensing DNA dari lokus CSF1PO, TH01, dan TPOX menggunakan experion DNA $1 \mathrm{~K}$ Analysis Kit sesuai protokol Bio-Rad.

Instrumen penelitian yang digunakan dalam penelitian ini adalah SPSS 20 untuk mengolah data karakteristik subyek penelitian dan software EasyDNA ${ }^{8}$ yang sesuai untuk data populasi dan selanjutnya didapatkan frekuensi alel, heterozigositas observasi dan power of discrimination (PD) dari lokus CSF1PO, TH01, dan TPOX.

\section{HASIL DAN PEMBAHASAN}

Pada tabel 1 didapatkan hasil bahwa karakteristik dari subyek penelitian adalah subyek berasal dari etnis Minangkabau asli, usia dewasa muda. Sebesar 33,3\% subyek berjenis kelamin laki-laki, dan 
perempuan $66,7 \%$. Pendidikan subyek $70 \%$ adalah mahasiswa.

Berdasarkan tabel 2 didapatkan bahwa pada penelitian ini lokus CSFP01 terdapat pengulangan AGAT sebanyak 13 kali (165 bp), untuk lokus THO1 dengan pengulangan
TCAT sebanyak 7 kali (87 bp) dan untuk lokus TPOX dengan pengulangan AATG sebanyak 8 kali (78 bp). Frekuensi alel pada sampel etnis Minangkabau dengan menggunakan tiga lokus dapat dilihat pada tabel 2.

Tabel 1. Karakteristik dasar subjek

\begin{tabular}{llcc}
\hline \multicolumn{1}{c}{ Data } & \multicolumn{1}{c}{ Klasifikasi } & Jumlah $(\mathrm{n})$ & Persentase (\%) \\
\hline Jenis kelamin & Laki-laki & 10 & 33,3 \\
& Perempuan & 20 & 66,7 \\
& Total & 30 & 100,0 \\
\multirow{4}{*}{ Umur } & $21-30$ & 24 & \\
& $31-40$ & 4 & 80,0 \\
& $41-50$ & 2 & 13,3 \\
\multirow{5}{*}{ Pendidikan } & Total & 30 & 6,7 \\
& & & 100,0 \\
& Tamat SLTA & 9 & 30,0 \\
& Perguruan Tinggi & 21 & 70,0 \\
& Total & 30 & 100,0 \\
\hline
\end{tabular}

Tabel 2. Frekuensi alel lokus CSF1PO, TH01, dan TPOX

\begin{tabular}{ccc}
\hline Lokus & Alel & Frekuensi \\
\hline CSF1PO & $156 \mathrm{bp}$ & 0,017 \\
& $158 \mathrm{bp}$ & 0,017 \\
& $159 \mathrm{bp}$ & 0,017 \\
& $160 \mathrm{bp}$ & 0,033 \\
& $161 \mathrm{bp}$ & 0,05 \\
& $162 \mathrm{bp}$ & 0,05 \\
& $163 \mathrm{bp}$ & 0,067 \\
& $165 \mathrm{bp}$ & 0,167 \\
& $166 \mathrm{bp}$ & 0,033 \\
& $167 \mathrm{bp}$ & 0,05 \\
& $168 \mathrm{bp}$ & 0,117 \\
& $169 \mathrm{bp}$ & 0,133 \\
& $170 \mathrm{bp}$ & 0,167 \\
& $171 \mathrm{bp}$ & 0,033 \\
& $172 \mathrm{bp}$ & 0,033 \\
& $175 \mathrm{bp}$ & 0,017 \\
& $89 \mathrm{bp}$ & 0,017 \\
& $90 \mathrm{bp}$ & 0,083 \\
& $91 \mathrm{bp}$ & 0,1 \\
& $92 \mathrm{bp}$ & 0,05 \\
& $93 \mathrm{bp}$ & 0,217
\end{tabular}

\begin{tabular}{cc}
$94 \mathrm{bp}$ & 0,083 \\
$95 \mathrm{bp}$ & 0,05 \\
$96 \mathrm{bp}$ & 0,017 \\
$98 \mathrm{bp}$ & 0,15 \\
$99 \mathrm{bp}$ & 0,1 \\
$101 \mathrm{bp}$ & 0,117 \\
$104 \mathrm{bp}$ & 0,017 \\
$81 \mathrm{bp}$ & 0,017 \\
$83 \mathrm{bp}$ & 0,067 \\
$84 \mathrm{bp}$ & 0,25 \\
$85 \mathrm{bp}$ & 0,267 \\
$87 \mathrm{bp}$ & 0,033 \\
$88 \mathrm{bp}$ & 0,017 \\
$91 \mathrm{bp}$ & 0,067 \\
$92 \mathrm{bp}$ & 0,1 \\
$93 \mathrm{bp}$ & 0,133 \\
$94 \mathrm{bp}$ & 0,05 \\
\hline
\end{tabular}

Berdasarkan tabel 3 menunjukkan nilai heterozigositas observasi tertinggi terdapat pada lokus TPOX diikuti oleh lokus TH01 dan lokus CSF1PO. Hasil amplifikasi ke tiga lokus (CSF1PO, TH01, dan TPOX) pada 
sampel etnis Minangkabau didapatkan 38 alel. Ragam alel paling banyak dihasilkan oleh lokus CSF1PO yaitu 16 alel, kemudian lokus TH01 sebanyak 12 alel, sedangkan ragam alel paling sedikit dihasilkan oleh lokus TPOX yaitu 10 alel. Lokus CSF1PO menghasilkan 16 ragam alel, dengan alel terpendek $156 \mathrm{bp}$ dan terpanjang $170 \mathrm{bp}$. Frekuensi tertinggi terdapat pada alel 165 bp $(0,0167)$ dan alel 170 bp $(0,0167)$ dan terendah pada alel $156 \mathrm{bp}(0,017), 158 \mathrm{bp}$ $(0,017), 158$ bp $(0,017)$ dan 175 bp $(0,017)$. Hasil amplifikasi pada lokus TH01 diperoleh 12 ragam alel, dengan alel terpendek 89 bp dan alel terpanjang 104 bp. Frekuensi tertinggi terdapat pada alel 93 bp $(0,217)$ dan terendah terdapat pada alel $89 \mathrm{bp}$ $(0,017), 96$ bp $(0,017)$ dan alel 104 bp $(0,017)$. Hasil amplifikasi pada lokus TPOX diperoleh 10 ragam alel, alel terpendek 81 bp dan alel terpanjang 94 bp dengan frekuensi tertinggi terdapat pada alel $85 \mathrm{bp}$ $(0,267)$ dan terendah pada alel $81 \mathrm{bp}$ $(0,017)$ dan alel $88 \mathrm{bp}(0,017)$.

Tabel 3. Nilai heterozigositas observasi dan Power of Discrimination 3 STR

\begin{tabular}{lcc}
\hline Lokus & $\begin{array}{c}\text { Heterozigositas } \\
(h)\end{array}$ & $\begin{array}{c}\text { Power of } \\
\text { Discrimination } \\
(P D)\end{array}$ \\
\hline CSF1PO & 0,2 & 0,98 \\
TH01 & 0,333 & 0,973 \\
TPOX & 0,4 & 0,949 \\
\hline
\end{tabular}

Alel pada lokus CSF1PO etnis Minangkabau yang memiliki frekuensi tertinggi yaitu alel 165 bp dan alel 175 bp, oleh karena itu alel 165 bp dan 175 bp diduga merupakan alel founding father lokus CSF1PO dari etnis Minangkabau. Alel pada lokus TH01 etnis Minangkabau yang memiliki frekuensi tertinggi adalah alel 93 bp $(0,217)$. Alel pada lokus TPOX etnis Minangkabau yang memiliki frekuensi tertinggi adalah alel 85 bp $(0,267)$. Alel founding father akan mengalami mutasi, sehingga terbentuk alel yang lebih panjang atau lebih pendek dengan frekuensi yang lebih rendah. Perubahan ragam alel dapat terjadi akibat adanya perkawinan.

Nilai frekuensi yang tinggi menunjukkan bahwa alel merupakan alel yang umum pada etnis Minangkabau. Frekuensi yang terlalu tinggi dalam satu lokus, menyebabkan penurunan nilai keragaman genetik dan PD. Nilai PD tertinggi terdapat pada lokus CSF1PO diikuti lokus TH01 dan TPOX. Nilai heterozigositas observasi dan PD dipengaruhi oleh ragam alel dan frekuensinya. Semakin banyak ragam alel yang ditemukan, maka semakin tinggi nilai heterozigositas observasi dan PD pada lokus tersebut. Semakin tinggi nilai heterozigositas observasi dan PD yang dihasilkan, maka lokus tersebut semakin baik digunakan dalam analisis DNA untuk keperluan forensik. Pada penelitian ini didapatkan nilai heterozigositas observasi tidak sebanding dengan PD.

Hasil penelitian analisis genetik pada etnis Minangkabau dengan penanda tiga lokus DNA mikrosatelit menunjukkan bahwa dari 3 lokus tersebut baik digunakan dalam analisis DNA untuk kepentingan forensik karena memberikan ragam alel lebih banyak sehingga PD-nya tinggi, namun heterozigositas observasi dari lokus ketiga lokus yang diperiksa rendah karena banyak alel homozigot. Semakin besar nilai 
pembeda maka semakin kecil peluang ditemukan dua orang yang tidak berhubungan keluarga memiliki genetik yang sama, sehingga semakin kecil kemungkinan orang yang tidak bersalah mendapat hukuman atas perbuatan yang tidak pernah dilakukannya.

Ragam frekuensi alel, heterozigositas observasi dan PD yang berbeda pada lokus CSF1PO, TH01 dan TPOX ditemukan pada penelitian Untoro dkk (2009) pada populasi Indonesia, ${ }^{9}$ Ozeki dan Tamaki (2013) pada populasi Jepang ${ }^{10}$ dan Rodriguez dkk (2015) dengan sampel orang Filipina ${ }^{11}$. Pada penelitian Untoro dkk (2009) dengan sampel Indonesia didapatkan data heterozigot observasi (ho) untuk lokus CSF1PO adalah 0,687 dengan PD adalah 0,868. ${ }^{9}$ Ho lokus TH01 adalah 0,735 dengan PD adalah 0,904. ${ }^{9}$ Ho lokus TPOX adalah 0,558 dengan PD adalah $0,7693 .{ }^{9}$ Pada penelitian oleh Zhang (2011) dengan sampel Chinese ${ }^{12}$, Toscanini (2003) dengan sampel Argentina ${ }^{13}$ juga didapatkan perbedaan nilai parameter forensik lokuslokus STR. Masih banyak penelitian lain terkait analisis genetika populasi terhadap lokus-lokus STR dari berbagai etnis/populasi di dunia. Perbedaan tersebut terjadi karena dipengaruhi oleh jumlah dan wilayah (etnis) dalam pengambilan sampel. Sampel etnis Minangkabau hanya 30 orang dan berada pada satu wilayah yang sempit. Perbedaan ukuran alel tersebut dapat disebabkan oleh adanya variasi antar ras yang terkait dengan cikal bakal pembentuk populasi (founding father). Variasi yang terjadi antar populasi juga terjadi akibat adanya mutasi DNA mikrosatelit.

\section{SIMPULAN}

Data mengenai frekuensi alel-alel dan data dasar tentang lokus CSF1PO, THO1 dan TPOX untuk populasi etnis Minangkabau di kota Padang telah berhasil didapatkan. Hasil penelitian analisis genetik pada etnis Minangkabau dengan penanda tiga lokus DNA mikrosatelit menunjukkan bahwa dari 3 lokus tersebut baik digunakan dalam analisis DNA untuk kepentingan forensik karena memberikan ragam alel lebih banyak. Saran pada penelitian berikutnya untuk mendapatkan hasil dengan tingkat ketelitian yang lebih tinggi perlu jumlah sampel yang lebih besar. Dalam aplikasinya untuk lebih memperkuat hasil uji statistik dalam proses identifikasi, perlu mengombinasi database ini dengan beberapa database lokus lain.

\section{DUKUNGAN FINANSIAL}

Dana penelitian didapatkan dari dana PNBP Fakultas Kedokteran Universitas Andalas tahun 2017.

\section{UCAPAN TERIMA KASIH}

Terima kasih untuk laboran Laboratorium Biomedik dan dokter muda Forensik periode September 2017 Fakultas Kedokteran Universitas Andalas. 


\section{DAFTAR PUSTAKA}

1. Purwanti SH. Dari Bom Bali hingga Tragedi Sukhoi. Jakarta: Rayyana Komunikasindo; 2013.

2. Syukriani Y. DNA Forensik. Jakarta: Sagung Seto; 2012.

3. Goodwin W, Linacre A, Hadi S. An Introduction to Forensic Genetics. West Sussex: John Wiley\&Sons Ltd; 2007.

4. Butler JM, Becker CH. Improved Analysis of DNA Short Tandem Repeats with Time-Of-Flight Mass Spectrometry (Science and Technology Research Report). Washington DC: US Department of Justice Office of Justice Program; 2001.

5. Butler JM. Forensic DNA Typing. $2^{\text {nd }}$ edition. New York: Elsevier Academy Press; 2005.

6. Rapley R, Whitehouse D. Basic Tools and Techniques in Molecular Biology: Molecular Forensic. West Sussex: John Wiley \& Sons, Ltd; 2007. P.20-34.

7. Baloglu H, Yigit N. A New Remedy in Pathology Practice: Molecular Solution to Sample Mix-Up. Turk Patoloji Derg. 2011; 27(2):106-109. doi: 10.5146/tjpath.2011.01057.

8. Fung WK, Yang CT, Guo W. EasyDNA: user-friendly paternity and kinship testing program. International Congress Series. 2004; 1261:628-630. doi: 10.1016/S0531-5131(03)01486-9.

9. Untoro E, Atmadja DS, Pu CE, Wu FC. Allele frequency of CODIS 13 in Indonesian population. Leg Med. 2009; 11(Supp.1):S203-205. doi: 10.1016/i.legalmed.2009.01.007.

10. Ozeki M, Tamaki K. Allele frequencies of 37 short tandem repeat loci in a Japanese population. Leg Med. 2013; 15(6):342-6. doi: 10.1016/j.legalmed.2013.08.006.

11. Rodriguez JJ, Salvador JM, Calacal GC, Laude RP, De Ungria MC. Allele frequencies of 23 autosomal short tandem repeat loci in the Philippine population. Leg Med. 2015; 17(4):295-7. doi: 10.1016/i.legalmed.2015.02.005.

12. Zhang Y. Population Genetics for 15 STR loci of Liaoning Han in Northeastern China. J Forensic Res. 2011; 2:123. doi: 10.4172/2157-7145.1000123.

13. Toscanini U, Berardi G, Haas E, Raimondi E. Data analysis of 10 STR loci in a population in the province of Neuquen, Argentina. International Congress Series. 2003; 1239:239-242. doi: 10.1016/S0531-5131(02)00583-6. 